\title{
Peran Lembaga Amil Zakat, Infaq dan Shadaqah Muhammadiyah (Lazismu) Banjarnegara dalam Meningkatkan Perekonomian Kaum Dhuafa
}

\author{
Sri Apriliyani*, Zaini Abdul Malik
}

Prodi Hukum Ekonomi Syariah, Fakultas Syariah, Universitas Islam Bandung, Indonesia.

*Sriapriliyani1@gmail.com , za.abuhibban@gmail.com

\begin{abstract}
The role of zakat is very important, for that the amil zakat institution is a mandate of responsibility in managing zakat. The purpose of this study was to determine, Firstly the Role of Zakat in Increasing Empowerment, Secondly the Role of the Amil Zakat Institution, Infaq and Sadaqah Muhammadiyah Banjarnegara in enhancing empowerment in carrying out its programs relating to the economic empowerment of the people, especially the poor. The type of data analysis used in this study is a qualitative descriptive analysis, with field research specifications. The results of this study indicate that the role of the Amil zakat, infaq and shadaqah institutions in improving the economy of the poor is to use productive zakat funds as a program in the form of venture capital distributed by the LAZISMU Banjarnegara. And there is a change in economic improvement mustahiq after getting productive zakat funds with the qharhul hasan contract (benevolent loans).
\end{abstract}

Keywords: Productive Zakat, LAZ Role, Economy, Economic Empowerment

\begin{abstract}
Abstrak. Peran zakat sangat penting, untuk itu lembaga amil zakat merupakan amanah tanggung jawab dalam pengelolaan zakat. Tujuan penelitian ini adalah untuk mengetahui, Pertama Peran Zakat dalam peningkatan pemberdayaan, Kedua Peran Lembaga Amil Zakat, infaq dan Shadaqah Muhammadiyah Banjarnegara dalam peningkatan pemberdayaan melaksanakan programnya yang berkaitan dengan pemberdayaan ekonomi umat khususnya kaum dhuafa. Jenis analisa data yang digunakan dalam penelitian ini adalah analisis deskriptif kualitatif, dengan spesifikasi penelitian field research (penelitian lapangan). Hasil dari penelitian ini menunjukkan bahwa peran dari Lembaga Amil zakat, infaq dan shadaqah dalam meningkatkan perekonomian kaum dhuafa yaitu dengan memanfaatkan dana zakat produktif salah satu program dalam bentuk modal usaha yang disalurkan oleh pihak LAZISMU Banjarnegara. Dan adanya perubahan peningkatan ekonomi mustahiq setelah mendapatkan dana zakat produktif dengan akad qharhul hasan (pinjaman kebajikan).
\end{abstract}

Kata Kunci: Zakat produktif, Peran LAZ, Perekonomian, Pemberdayaan Ekonomi 


\section{A. Pendahuluan}

\section{Latar Belakang Masalah}

Kemiskinan merupakan masalah terbesar dari masalah global yang dihubungkan dengan masalah perekonomian kebutuhan dan kesulitan dalam kekurangan menjalani kehidupan. Masalah kemiskinan merupakan salah satu penyebab munculnya masalah ekonomi perekonomian masyarakat, karena definisi itu sendiri adalah lemahnya sumber penghasilan yang mampu diciptakan individu masyarakat yang juga mengimplikasi akan lemahnya sumber penghasilan yang ada dalam masyarakat itu sendiri dalam memenuhi segala kebutuhan perekonomian dari kehidupannya. Kemiskinan merupakan bahaya besar bagi umat manusia dan tidak sedikit umat yang jatuh peradabannya hanya karena kefakiran. Seperti sabda Nabi Saw yang berbunyi.

كَادَ ألْفَقْرُ أَنْ يَكُوْنَ كُفْرًا

“kemiskinan itu dekat kepada kekufuran” (H.R Abu Na'im)

Abdurrachman Qadir dalam bukunya berjudul Zakat (Dalam Dimensi Mahdah dan Sosial) menjelaskan bahwa salah satu cara menanggulangi kemiskinan adalah dukungan orang yang mampu untuk mengeluarkan harta kekayaan mereka berupa dana zakat kepada mereka yang kekurangan.

Zakat kekayaan yang akan memberi pertolongan kepada mustahiq yang mempunyai usaha. Prinsip yang terkandung dalam zakat cukuplah sederhana yaitu apabila telah cukup untuk hari ini, tolonglah orang lain agar orang menolongmu. Peran dana zakat mampu meningkatkan perekonomian, Adapun penyaluran yang dilakukan oleh LAZISMU Banjarnegara melalui bantuan modal usaha kepada mereka yang sudah mempunyai usaha, dan sektor usaha yang dimodali oleh pihak LAZISMU Banjarnegara adalah usaha kecil seperti: usaha pedagang kecil, pertanian dan usaha-usaha kecil lainnya, dan untuk tahap pertama pemberian modal usaha yang diberikan pihak lembaga kepada mustahiq dan dikembalikan dengan akad qardhul hasan yaitu pinjaman kebajikan tanpa adanya bunga.

Modal usaha yang diberikan dalam bentuk modal usaha dana bergulir memberikan manfaat untuk membiayai usaha produktif, memperoleh sarana produksi secara terus menerus, meningkatkan perekonomian dan pendapatan yang diperoleh sebagai akibat tambahan modal dalam usaha produktif. Hal ini dapat mengurangi ketergantungan nasabah (mustahiq) dari lintah darat (rentenir) yang memiliki bunga cukup besar. LAZISMU Banjarnegara menyediakan usaha produktif bagi mustahiq sehingga mereka dapat mengembangkan ekonomi keluarga mereka sendiri, dan mampu meningkatkan pendapatan mustahiq dari sebelumnya menjadi lebih baik dengan menggunakan skema akad qardhul hasan.

Dari segi manajemen zakat sudah dapat dikatakan adanya perubahan perekonomian dan peningkatan ekonomi, namun dari segi akad adanya potongan pembiayaan sedangkan peminjam mengembalikan secara untuk yaitu nominal awal peminjaman. Pelaksanaan qardhul hasan di LAZISMU Banjarnegara tidak sesuai dengan prinsip teori al-qardh al-hasan dengan Hal ini menjadikan program pemberdayaan tersebut belum bisa berjalan secara maksimal karena kurangnya pendampingan dan evaluasi dari pengelola program.

Tujuan Penelitan Berdasarkan uraian rumusan masalah di atas, maka penelitian ini dilakukan dengan tujuan sebagai berikut: Untuk Mengetahui Peran Zakat dalam Pemberdayaan Ekonomi., Untuk Mengetahui Peran Lembaga Amil Zakat, Infaq dan Shadaqah Muhammadiyah (LAZISMU) dalam Pemberdayakan Ekonomi.

\section{B. Landasan Teori}

\section{Teori Zakat}

Menurut bahasa, zakat berasal dari kata " zaka” yang artinya berkah, tumbuh, bersih dan baik. Sedangkan menurut bahasa Arab, arti dasar dari kata zakat, ditinjau dari segi bahasa adalah, suci, tumbuh, berkah dan terpuji. Semua arti dari zakat tersebut telah disebutkan dalam AlQuran dan Hadits. Zakat dalam istilah fiqih berarti sejumlah harta tertentu yang diwajibkan Allah SWT diserahkan kepada orang-orang yang berhak.

Menurut segi Bahasa, kata zakat merupakan kata dasar (masdar) dari zaka yang berarti 
berkah, tumbuh, bersih, dan baik. Sesuatu itu zaka, berarti tumbuh dan berkembang, dan seorang itu zaka, berarti orang itu baik. Tetapi yang terkuat, menurut wahidi dan lain-lain, kata dasar zaka berarti bertambah dan tumbuh, sehingga bisa dikatakan, tanaman itu zaka, artinya tumbuh, sedanagkan tiap sesuatu yang bertambah disebut zaka artinya bertambah. Bila satu tanaman tumbuh tanpa cacat, maka kata zaka disini berarti bersih. Dan bila seseorang diberi sifat zaka dalam arti baik, maka berarti orang itu lebih banyak mempunyai sifat yang baik. Seorang itu zaki, berarti seorang yang memiliki lebih banyak sifat-sifat orang baik, dan kalimat "hakim-zaka-saksi" berarti hakim mengatakan jumlah saksi-saksi diperbanyak.

Zakat dari segi istilah fikih berati "sejumlah harta tertentu yang diwajibkan Allah diserahkan kepada orang-orang yang berhak" di samping berarti "mengeluarkan jumlah tertentu itu sendiri". Jumlah yang dikeluarkan itu disebut zakat karena yang dikeluarkan itu menambah banyak, membuat lebih berarti, dan melindungi kekayaan itu dari kebinasaan.

Menurut Didin Hafidhudin, ditinjau dari segi bahasa zakat mempunyai beberapa arti, yaitu Al-Baraktu "keberkahan", Al-Namaa" pertumbuhan dan perkembangan," Ath Thaharatu, kesucian, dan Ash Shalahu "keberesan". Sedangkan secara istilah yaitu bahwa zakat adalah bagian dari harta dengan persyaratan tertentu yang Allah Swt mewajibkan kepada pemiliknya untuk diserahkan kepada yang berhak menerimanya dengan persyaratan tertentu pula.

Hubungan antara pengertian zakat menurut bahasa dan dengan pengertian menurut istilah, sangat nyata dan erat, yaitu bahwa harta yang dikeluarkan zakatnya akan menjadi berkah, tumbuh, berkembang dan bertambah, suci dan beres (baik).

Zakat melaksanakan tugasnya dalam mewujudkan bertambahnya produktivitas dalam harta. Zakat sebagai sirkulator yang mewujudkan kepentingan dan terpenuhinya kebutuhan bagi mereka yang mengeluarkannya dan juga bagi mereka bagi menerimanya.

Kedudukan zakat di dalam Islam adalah menjadi soal yang terpenting tentang matinya umat Islam sendiri. Sebagai orang tidak dapat lahir ke dalam dunia dengan roh semata-mata, demikian juga Islam tidak dapat lahir kuat dan kuasa bila dalam isi pelajaran dan pendidikan tidak termasuk hukum zakat yang menjadi dasar ilmu ekonomi. Kewajiban zakat dijelaskan dalam al-Qur'an dan hadits Nabi sebagai berikut:

Sebagaimana Allah Ta'ala berfirman,

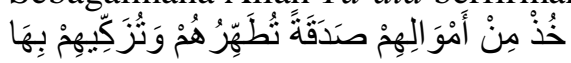

"Ambillah zakat dari sebagian harta mereka, dengan zakat itu kamu membersihkan dan mensucikan mereka" (QS. At Taubah: 103).

Dan firman Allah yang lain tentang zakat, yaitu:

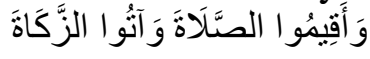

"Dirikanlah shalat dan bayarlah zakat hartamu"

Adapun dalam hadits diantaranya adalah:

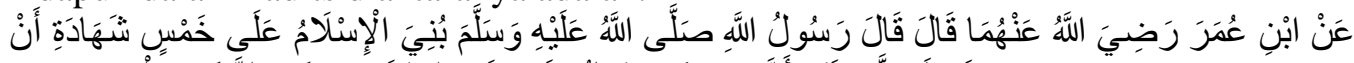



Dari Ibnu Umar, Rasulullah Saw. bersabda: "Islam dibangun di atas lima pundasi pokok, yakni kesaksian tiada Tuhan selain Allah dan bahwa Muhammad utusan Allah, mendirikan sholat, menunaikan zakat, melaksanakan haji, dan puasa di bulan Ramadhan". (HR. Imam Bukhari).

Zakat bagi umat Islam, khususnya di Indonesia dan bahkan juga dunia Islam pada umumnya, sudah diyakini sebagai bagian pokok ajaran Islam yang harus ditunaikan. Dalam perbincangan perspektif fiqh pun, kewajiban zakat tidak pernah menjadi bahan yang diperdebatkan oleh kalangan ulama, karena dasar kewajiban dari ibadah ini sangat jelas baik berdasarkan al-Qur'an maupun hadist Nabi.

\section{Teori Pemberdayaan}

Secara konseptual, pemberdayaan atau pemberkuasaam (empowerment), berasal dari kata power (kekuasaan atau keberdayaan). Karenanya, ide utama pemberdayaan bersentuhan dengan konsep mengenai kekuasaan. Kekuasaan seringkali dikaitkan dengan kemampuan kita untuk oranglain melakukan apa yang kita inginkan. Kekuasaan tercipta dalam konteks relasi antar manusia. Karena itu, kekuasaan dan hubungan kekuasaan dapat berubah. Dengan pemahaman 
kekuasaan seperti ini, pemberdayaan sebagai sebuah proses perubahan kemudian memiliki konsep yang bermakna.

Pemberdayaan menunjuk pada kemampuan orang, khususnya kelompok rentan dan lemah sehingga mereka memiliki kekuatan atau kemampuan dalam (a) Memenuhi kebutuhan dasarnya sehingga mereka memiliki kebebasan, dalam arti bukan saja bebas mengemukakan pendapat, melainkan bebas dari kelaparan, bebas dari kebodohan, bebas dari kesakitan. (b) Menjangkau sumber-sumber produktif yang memungkinkan mereka dapat meningkatkan pendapatannya dan memperoleh barang dan jasa mereka perlukan. (c) Berpartisipasi dalam proses pembangunan dan keputusan-keputusan yang mempengaruhi mereka.

Memberdayakan ekonomi adalah upaya untuk perekonomian lapisan masyarakat yang dalam kondisi sekarang tidak mampu untuk melepaskan diri dari perangkap kemiskinan dan keterbelakangan. Memberdayakan masyarakat melibatkan proses dan tindakan sosial dimana penduduk sebua komunitas mengorganisasikan diri dalam membuat perencanaan dan tindakan kolektif untuk memecahkan sosial atau memenuhi kebutuhan sosial sesuai dengan kemampuan masyarakat dilakukan melalui proses:

1. Merancang program perbaikan kehidupan sosial ekonomi,

2. Memobilisasi sumberdaya setempat.

3. Memecahkan masalah sosial.

4. Menciptakan atau membuka akses bagi pemenuhan kebutuhan.

5. Menjalin kerjasama dengan berbagai pihak yang relavam dengan konteks pemberdayaan masyarakat.

Berkaitan dengan pemberdayaan ekonomi masyarakat, Musa Asy'arie berpendapat bahwa institusi perlu mendorong supaya masyarakat berlatih dan mempersiapan dirimya untuk memilih peluang menjadi wirausaha, dengan memberikan bekal pelatihan sebagai bekal yang sangat penting ketika akan memasuki dunia wirausaha. Program pembinaan berkelanjutan itu, dapat dilakukan melalui beberapa tahap, yaitu:

1. Pelatihan usaha melalui pelatihan ini, setiap peserta pemahaman terhadap konsep kewirausahaan, dengan segala maca seluk beluk permasalahan yang ada didalamnya. Tujuan dari pelatihan ini adalah untuk memberikan wawasan yang lebih menyeluruh dan aktual, sehingga dapat menumbuhkan motivasi terhadap peserta, disamping diharapkan peserta memiliki pengetahuan teoritis tentang penguasaan teknik kewirausahaan dalam berbagai aspeknya.

2. Pemodalan dalam bentuk uang, merupakan salah satu faktor penting dalam dunia usaha, tetapi buka yang terpenting. Untuk mendapatkan dukungan keuangan yang cukup stabil, perlu mengadakan hubungan kerjasama yang baik dengan lembaga keuangan, baik perbankan maupun dana bantuan yang disalurkan melalui kemitraan usaha lainnya.

Penambahan modal dari lembaga keuangan, sebaiknya diberikan bukan untuk pemodalan awal, tetapi untuk modal pengembangan, setelah usaha itu telah dirintis dan menunjukan perkembangan profit yang baik. Karena jika usaha itu belum menunjukkan perkembangan yang baik, kemudin dana yang dipakai dana berbunga, maka seringkali menjadi penyebab sulitnya usaha berkembang, karena profit yang ada habis untuk membanyar bunga.

3. Pendampingan pada tahap ini yaitu ketika usaha itu dijalankan, maka wiraswasta akan didampingi oleh tenaga pendamping yang profesional, yang berfungsi sebagai pengaruh maupun sekaligus pembimbing, sehingga kegiatan usaha yang digelutinya, benar-benar mampun berhasil dikuasainya, maka memungkinkan diadakannya usaha-usaha pengembangan. Jadi tahap pendampingan adalah penguatan agar usaha yang dikembangkan dapat dilakukan benar-benar berjalan mantap. Tahap pendampingan dapat dilakukan secara periodik, sesuai dengan perkembangan permasalahan yang dihadapi.

Perubahan ini merupakan langkah-langkah dasar yang meliputi pengalokasian sumber daya, penguatan kelembagaan, penguasaan teknologi, serta pemberdayaan manusia. Dalam upaya ini Gunawan Sumodiningrat mengemukakan pilihan kebijakan dilaksanakan dalam beberapa langkah strategis ialah: 
a. Memperkuat posisi transaksi dan kemitraan usaha ekonomi masyarakat. Upaya yang tidak kalah pentingnya dalam memperkuat posisi transaksi dan kemitraan usaha ekonomi ini adalah dengan pendekatan bersama.

b. Posisi industrilisasi harus mengarah ke daerah pedesaan dengan memnfaatkan potensi setempat yang umumnya agro industri.

c. Kebijakan ketenagakerjaan yang mendorong tumbuhnya tenaga kerja mandiri sebagai cikal bakal lapisan wirausaha baru, yang berkembang menjadi wirausaha kecil dan menengah yang kuat dan saling menunjang. Pemberdayaan masyarakat adalah sebuah proses dan tujuan. Sebagai proses, pemberdayaan adalah serangkaian kegiatan untuk memperkuat keberdayaan kelompok dakan masyarakat, termasuk individu-individu yang mengalami masalah kemiskinan.

\section{Hasil Penelitian dan Pembahasan}

Peran LAZISMU Banjarnegara dalam meningkatkan perekonomian kaum dhuafa sudah berjalan dengan baik sehingga dapat meningkatkan ekonomi para mustahiqnya dan dapat mengubah mustahiq menjadi muzakki. Adanya perubahan perekonomian yang sudah berkembang dengan baik yaitu dengan adanya pemberian modal usaha kepada orang yang tergolong berhak menerima zakat dan kemudian dikembangkan untuk memenuhi kehidupan mereka dimasa yang akan datang. Pemberian dana zakat ditunjukan untuk dproduktifkan agar lebih membantu dalam meningkatkan perekonomian mustahiq.

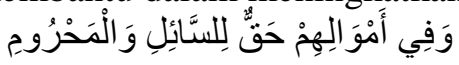

"Dan pada harta-harta mereka ada hak untuk orang miskin yang meminta dan orang miskin yang tidak mendapat bagian.”.(QS. Adz-Dzariyat)

Salah satu yang dilaksanakan oleh LAZISMU Banjarnegara adalah menyalurkan dana zakat secara produktif tujuan dari program ini adalah untuk memberdayakan ekonomi mustahiq dengan cara memberikan modal usaha yang produktif dengan adanya dana bergulir dengan skema akad qardhul hasan. Dalam program ini mustahiq yang memperoleh modal usaha dapat menggunakan dana tersebut untuk meningkatkan usahanya. Utang-piutang yang sekarang ini lebih dikenal sebagai pinjaman kebajikan (al-qardh al-hasan). Pengembangan zakat bersifat produktif dengan cara dijadikannya dana zakat sebagai modal usaha, untuk pemberdayaan ekonomi penerimanya, dan fakir miskn dapat menjalankan atau membiayai kehidupannya secara konsisten. Dana zakat tersebut akan dapat mendapatkan penghasilan yang membaik, mampu meningkatkan usaha, mampu mengembangkan usaha, namun yang terjadi dilembaga tersebut tidak sesuai dengan praktif akad qardhul hasan karena adanya pemotongan peminjaman namun si peminjam harus mengembalikan pinjaman secara utuh. Dalam buku "fiqh muamalah" oleh Amad Wardi Muslih. Para ulama bersepakat bahwa setiap utang yang mengambil manfaat hukumnya haram, apabila hal itu diisyaratkan atau ditetapkan dalam perjanjian. Hal ini sesuai dengan kaidah:

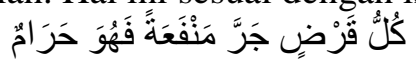

"semua yang menarik manfaat, maka ia termasuk haram" (hadits riwayat Al-Harits Abi Usamah"

\section{Kesimpulan}

1. Peran dana zakat produktif di LAZISMU Banjarnegara sudah berjalan dengan bagus, sebelum modal usaha diberikan pada mustahiq pihak LAZISMU pun memberikan pembinaan terhadap mustahiq terlebih dahulu. Sebelum mendapatkan dana zakat produktif tidak ada perubahan ekonomi mustahiq, dan setelah mendapatkan dana zakat produktif adanya peningkatan pendapatan ekonomi mustahik dari sebelumnya. Pengguliran modal kepada anggota LAZISMU didasarkan akad pinjaman tanpa bunga namun dari segi praktiknya di LAZISMU Banjarnegara tidak sesuai dengan prinsip akad qardhul hasan (pinjaman kebajikan).

2. Peran Lembaga Amil Zakat, Infaq dan shadaqah dalam meningkatkan ekonomi mustahiqnya Terdiri dari: pertama, Penguatan karakter berbisnis, pelatihan dan motivasi untuk berbisnis. Kedua. Pembinaan dan pendampingan dalam menjalankan program 
usaha.

\section{Daftar Pustaka}

[1]. Al-Ba’'Iy, (2006), Ekonomi Zakat, Jakarta: Raja Grafindo Persada

[2]. Abi Abdullah Muhammad Bin Ismail Al-Buhari, Matan Buhari, Juz Awal, Darul Fiqr, Bairut

[3]. Departemen Agama Republik Indonesia, (2005), Al-quran dan terjemahan, Bandung: Kiaracondong

[4]. Hafidhudin Didin, (1998), Zakat Dalam Pedoman Perekonomian Modern, Jakarta: Gema Insani

[5]. Musa Asy' ari, Islam, (1997), Etos Kerja dan Pemberdayaan Ekonomi, Yogyakarta: Lesfi

[6]. Sumodiningrat Gunawan, Membangun Perekonomian Rakyat, Yogyakarta: Pustaka Pelajar

[7]. Qardhawi Yusuf,(2010), Hukum Zakat, Bogor: Litera Antar Nusa

[8]. Qardhawi Yusuf, (2010), Hukum Zakat Studi Komperatif Mengenai Status Dan Filsafat Zakat Berdasarkan Qur'an Dan Hadist, Jakarta: Litera Antar Nusa,

[9]. Yusuf Qardhawi, (2005), Spektrum Zakat Dalam Membangun Ekonomi Kerakyatan, Jakarta: Zikrul Hakim

[10]. Sahri Muhammad, (1982), Pengembangan Zakat \& Infak dalam Meningkatkan Kesejahteraan Masyarakat, Malang: Yayasan Pusat Studi: Avicenna

[11]. Suharto Edi, (2002), Membangun Masyarakat Memberdayakan Rakyat, Kajian Strategis Pembangunan Kesejahteraan Sosial \& Pekerjaan Sosial, Bandung: PT Refika Aditama

[12]. Qadir Abdurrahman, (2001), Zakat dalam Dimensi Mahdah dan Sosial, Jakarta: Raja Grafindo Persada, ed. 1, cet 2 